\title{
Intestinal immunisation with Escherichia coli protects rats against Escherichia coli induced cholangitis
}

\author{
B D L Aagaard, M F Heyworth, A L Oesterle, A L Jones, L W Way
}

\begin{abstract}
Background-Cholangitis, an infection of the biliary tract, is most commonly caused by Gram negative bacteria, particularly Escherichia coli. Factors governing the severity of cholangitis, including the role of biliary $\operatorname{IgA}$, are poorly understood.

Aims-The aim of this work was to find out if biliary IgA directed against $E$ coli protects rats against hepatobiliary infection with $E$ coli.
\end{abstract}

Subjects-Male Sprague-Dawley rats weighing 270-350 grams were used in all of the experiments.

Methods-At laparotomy, rats were immunised by injecting killed $E$ coli or normal saline (controls) into Peyer's patches. With or without subsequent antigenic boosting (by oral administration of killed $E$ coli), bile was collected at a second laparotomy, and rats were infected by introducing viable $E$ coli into the bile duct. Production of IgA anti-E coli antibody was measured by enzyme linked immunosorbent assay of bile, and the presence of hepatobiliary infection was determined by quantitative culture of liver homogenates.

Results-Systemic infection was present in six of 12 control rats and in one of 24 immunised rats $(p=0.005)$ after death. There was an inverse correlation between immunisation and $E$ coli colony counts in cultured liver homogenates $(p=0 \cdot 024)$.

Conclusion-The findings suggest that biliary IgA directed against $E$ coli protected rats against hepatobiliary $E$ coli infection and systemic sepsis.

(Gut 1996; 39: 136-140)

Surgical Service and Cell Biology Section, VA Medical Center, San Francisco, USA

Departments of Surgery and Medicine, University of California, San Francisco, USA B D L Aagaard M F Heyworth A L Oesterle A L Jones L W Way Correspondence to: Service (112), VA Medical Service (112), VA Medic Center, 4150 Clemen Street, San Francisco, CA 94121, USA.

Accepted for publication 31 January 1996
Keywords: cholangitis, biliary IgA, common bile duct, bile.

Cholangitis, an infection of the biliary tract, is usually associated with obstruction of the common bile duct. Gram negative enteric bacteria, in particular Escherichia coli, cause most of these infections. The disease ranges from a mild transient illness to lethal sepsis, but the factors that govern the severity are poorly understood. One possibility is that the course is influenced by biliary $\operatorname{IgA}$ directed against the bacteria responsible for the infection.

Previous studies have shown that oral, intraduodenal, or intra-Peyer's patch administration of antigen to rats can lead to a biliary IgA antibody response, but the functional role of biliary IgA has not been extensively studied. In particular, little is known about the potential of biliary IgA antibody to protect mammals against $E$ coli induced cholangitis. The aim of this study was to discover if biliary IgA antibody, induced by injecting killed $E$ coli into rat Peyer's patches, protects against biliary infection with $E$ coli.

\section{Methods}

\section{Animals}

Male Sprague-Dawley rats weighing 270-350 grams were used in all of the experiments. The animals were housed under standard conditions and had free access to standard laboratory chow (Purina Rodent Laboratory Chow 5001) and water.

\section{Bacteria}

E coli (ATCC 25922; American Type Culture Collection, Rockville, Maryland) were grown on Mueller-Hinton agar (DIFCO Laboratories, Detroit, Michigan) and frozen for storage in vials of milk at $-80^{\circ} \mathrm{C}$. A single lot of $E$ coli was used throughout the study.

Bacteria were killed by suspending thawed and recultured $E$ coli in $15 \mathrm{ml}$ of $10 \%$ formalin at $25^{\circ} \mathrm{C}$ for 15 minutes. The bacterial suspension was centrifuged, and the pellet was resuspended in $10 \mathrm{ml}$ of sterile normal saline and re-centrifuged. This washing procedure was repeated four times, and the killed $E$ coli were then suspended in sterile normal saline $\left(2.5 \times 10^{8}\right.$ organisms $\left./ \mathrm{ml}\right)$ for injection into Peyer's patches. A $100 \mu \mathrm{l}$ aliquot of each sample of killed $E$ coli was plated on a MuellerHinton agar plate, which was then incubated overnight at $37^{\circ} \mathrm{C}$ to verify complete killing of the bacteria.

\section{Experimental protocol}

The study comprised two phases: phase 1 consisted of establishing the method for immunising rats (intra-Peyer's patch injection of killed $E$ coli), and phase 2 determined whether immunisation could protect rats against bacterial cholangitis. Phase 2 involved two groups of rats (Table). Surgery was performed under aseptic conditions using intraperitoneal pentobarbital sodium $(60 \mathrm{mg} / \mathrm{kg}$ body weight) for general anaesthesia. All surgical procedures were performed via a midline laparotomy after shaving the abdomen and 
Experimental protocol for phase 2

\begin{tabular}{|c|c|c|c|c|c|}
\hline \multirow[b]{3}{*}{$\begin{array}{l}\text { Time } \\
\text { (days) }\end{array}$} & \multicolumn{2}{|l|}{ Group 1} & \multicolumn{3}{|l|}{ Group 2} \\
\hline & \multirow[b]{2}{*}{$\begin{array}{l}\text { Immunised } \\
(n=13)\end{array}$} & \multirow[b]{2}{*}{$\begin{array}{l}\text { Control } \\
(n=11)\end{array}$} & \multicolumn{2}{|l|}{ Immunised } & \multirow{2}{*}{$\begin{array}{l}\text { Control } \\
C \\
(n=12)\end{array}$} \\
\hline & & & $\begin{array}{l}A \\
(n=12)\end{array}$ & $\begin{array}{l}B \\
(n=12)\end{array}$ & \\
\hline 0 & \multirow{5}{*}{$\begin{array}{l}\text { killed } E \text { coli } \\
\text { (IPP) } \\
\text { collect bile } \\
\text { live } E \text { coli (IBD) } \\
\text { death }\end{array}$} & \multirow{5}{*}{$\begin{array}{l}\text { saline } \\
\text { (IPP) } \\
\text { collect bile } \\
\text { live } E \text { coli (IBD) } \\
\text { death }\end{array}$} & $\begin{array}{l}\text { killed } E \text { coli } \\
\text { (IPP) }\end{array}$ & $\begin{array}{l}\text { killed } E \text { coli } \\
\text { (IPP) }\end{array}$ & $\begin{array}{l}\text { saline } \\
\text { (IPP) }\end{array}$ \\
\hline 7 & & & killed $E \operatorname{coli}(\mathrm{O})$ & $\begin{array}{l}\text { killed } E \text { coli } \\
\quad+\mathrm{CT}(\mathrm{O})\end{array}$ & saline $(\mathrm{O})$ \\
\hline 10 & & & & & \\
\hline 12 & & & $\begin{array}{l}\text { collect bile } \\
\text { live } E \text { coli } \\
\text { (IBD) }\end{array}$ & $\begin{array}{l}\text { collect bile } \\
\text { live } E \text { coli } \\
\text { (IBD) }\end{array}$ & $\begin{array}{l}\text { collect bile } \\
\text { live } E \text { coli } \\
\text { (IBD) }\end{array}$ \\
\hline 15 & & & $\begin{array}{l}\text { ligate CBD } \\
\text { death }\end{array}$ & $\begin{array}{l}\text { ligate CBD } \\
\text { death }\end{array}$ & $\begin{array}{l}\text { ligate CBD } \\
\text { death }\end{array}$ \\
\hline
\end{tabular}

IPP: intra-Peyer's patch injection; IBD: intra-bile duct injection; CBD: common bile duct; $\mathrm{O}$ : oral administration; CT: cholera toxin.

preparing the skin with povidone-iodine solution (Betadine). At the conclusion of the procedure, the abdomen was closed in two layers using 5-0 Dexon and 4-0 silk.

Phase 1

Using a 30 gauge needle, the Peyer's patches of 25 rats were injected with $2.5 \times 10^{8}$ formalin killed $E$ coli suspended in $1 \mathrm{ml}$ of sterile normal saline. The number of Peyer's patches injected ranged from 7 to 11 per animal. Control rats $(n=7)$ underwent intra-Peyer's patch injection with $1 \mathrm{ml}$ of sterile normal saline and were otherwise treated the same as the immunised rats. At a second laparotomy 3, 5, 7, 9, or 14 days after injection, the common bile duct was cannulated with sterile PE-10 plastic tubing, and bile was collected. The rats were then killed by intra-cardiac injection of a lethal dose of pentobarbital sodium, followed by bilateral thoracotomy. Anti- $E$ coli IgA was quantified in the bile samples by enzyme linked immunosorbent assay (ELISA).

Phase 2

Group 1 experimental rats $(n=13)$ were immunised by injecting $2.5 \times 10^{8}$ formalin killed $E$ coli into their Peyer's patches, and control rats $(n=11)$ were injected with sterile normal saline by the same route. Seven days after injection, bile was collected by cannulating the common bile duct as described above. Live $E$ coli $\left(10^{4}-10^{6}\right.$ organisms in $0.1 \mathrm{ml}$ of sterile normal saline) were then introduced into the bile duct, the cannula was removed, and the bile duct was ligated. Seventy two hours later, all surviving animals were anaesthetised by intra-peritoneal injection of pentobarbital sodium, and $1 \mathrm{ml}$ of blood was obtained by sterile cardiac puncture for blood culture. The animals were then immediately killed as previously described. Bile and the right lobe of the liver were removed for postmortem analysis.

Group 2 experimental rats $(n=24)$ were immunised by injecting $2.5 \times 10^{8}$ formalin killed $E$ coli into Peyer's patches as previously described. Seven days later, 12 of these rats were orally boosted via a blunt ended feeding needle with $6.9 \times 10^{8}$ killed $E$ coli, and the remaining 12 rats were orally boosted with
$6.9 \times 10^{8}$ killed $E$ coli plus $0.04 \mathrm{mg}$ whole cholera toxin (List Biological Laboratories, Campbell, California). Control rats $(n=12)$ had sterile normal saline injected into their Peyer's patches, followed by sham oral boosting with saline seven days later. Five days after boosting, the common bile duct was cannulated, bile was collected, and $10^{7}$ live $E$ coli were introduced into the common bile duct, which was then ligated. Seventy two hours later, any surviving rats were killed in the same fashion as for group 1 rats. Intra-cardiac blood, bile, and the entire liver were collected for analysis.

\section{ELISA for anti-E coli $\operatorname{Ig} A$ in bile}

The wells of flexible assay plates (Falcon 3912; Becton Dickinson, Oxnard, California) were coated with $100 \mu$ l of formalin killed $E$ coli $\left(10^{8}\right.$ organisms $/ \mathrm{ml}$ suspended in $1 \mathrm{M}$ sodium carbonate, $\mathrm{pH} 9.5$ ) for four hours at $25^{\circ} \mathrm{C}$. ${ }^{1}$ After washing with phosphate buffered saline (Dulbecco's PBS, pH 7.5; Sigma Chemical Co, St Louis, Missouri), the wells were blocked with $1 \%$ bovine serum albumin in deionised $\mathrm{H}_{2} \mathrm{O}$ (essential fatty acid free bovine albumin; Sigma Chemical Co) for two hours at $25^{\circ} \mathrm{C}$. After washing with PBS, $100 \mu \mathrm{l}$ of bile (diluted in PBS from 1:50 to 1:3200) were added to duplicate wells, and the plates were incubated overnight at $4^{\circ} \mathrm{C}$. The plates were again washed with PBS, and $100 \mu l$ of 1:1000 peroxidase conjugated antirat IgA (Zymed Laboratories Inc, South San Francisco, California) were added to the wells, and the plates were incubated for four hours at $25^{\circ} \mathrm{C}$. After washing the plates with PBS, $100 \mu$ l of substrate solution consisting of $25 \mathrm{ml}$ citrated phosphate buffer ( $\mathrm{pH} 5 \cdot 0$ ), $10 \mu 130 \%$ hydrogen peroxide, and $10 \mathrm{mg} 0-$ phenylenediamine (Sigma Chemical Co) were added to the wells, and the reaction was allowed to proceed for 15 minutes in a light free container. The reaction was stopped by the addition of $50 \mu \mathrm{l}$ of $2 \mathrm{~N}$ sulphuric acid to each well. Plates were read at $490 \mathrm{~nm}$ in an automated ELISA reader (EL 310; BIO-TEK Instruments Inc, Winooski, Vermont). Each assay included bile from immunised and control rats, plus a rabbit antiserum control (rabbit anti-E coli antibody, followed by peroxidase conjugated swine antirabbit immunoglobulin, both obtained from Dako Corporation, Carpinteria, California). Mean optical density $\left(\mathrm{OD}_{490}\right)$ values were calculated for duplicate wells.

\section{Polyacrylamide gel electrophoresis and western} blotting

A lysate of $E$ coli was prepared as outlined by Hitchcock and Brown. ${ }^{2}$ The lysate was loaded on a $12 \%$ acrylamide gel and electrophoresed at $200 \mathrm{~V} / 100 \mathrm{~mA}$ for 60 minutes. ${ }^{3}$ Proteins were transferred from gels to nitrocellulose sheets by electrophoresis at $100 \mathrm{~V} / 500 \mathrm{~mA}$ for 60 minutes. ${ }^{4}$ After blocking with $1 \%$ casein for 30 minutes, each nitrocellulose sheet was cut into individual strips, which were incubated 


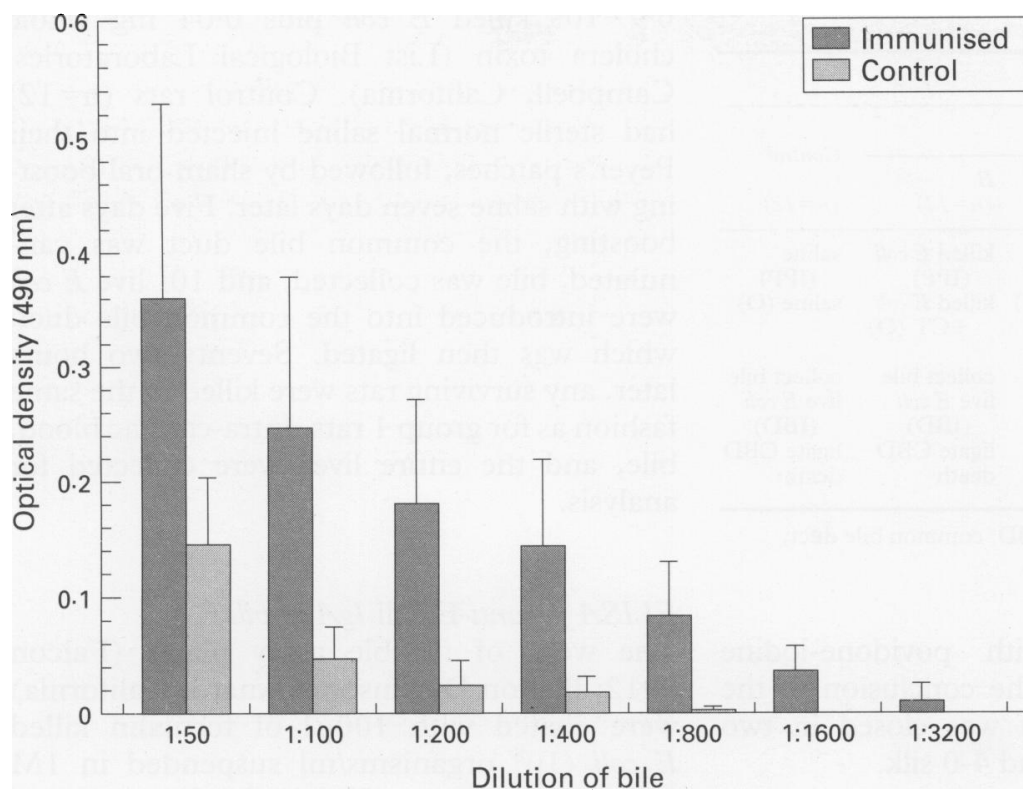

Figure 1: Results of ELISA for anti-E coli $\operatorname{Ig} A$ in bile from immunised rats $(n=13)$ and from control rats $(n=11)$ in phase 2 , group 1 . Anti-E coli IgA levels are expressed as optical density $\left(O D_{490}\right)$. Mean values and standard deviations are shown.

overnight with bile samples diluted $1: 100$ in $0.1 \mathrm{M}$ TRIS $/ 1 \%$ casein $(\mathrm{pH} 8 \cdot 3)$ at $4^{\circ} \mathrm{C}$. Next, the transblots were washed with PBS and incubated for 3.5 hours with a 1:500 dilution of alkaline phosphatase conjugated sheep antirat IgA (The Binding Site, University of Birmingham Research Institute, Birmingham, UK) in TRIS $/ 1 \%$ casein ( $\mathrm{pH} 8 \cdot 3$ ). The strips were then washed with PBS followed by further washing with TRIS buffer. A substrate solution, consisting of naphthol $(1 \mathrm{mg} / \mathrm{ml})$ and fast red $(2 \mathrm{mg} / \mathrm{ml}$; Sigma Chemical Co) in 50 $\mathrm{mM}$ TRIS buffer ( $\mathrm{pH} \mathrm{8.0)}$ ), was added. The enzymatic reaction was allowed to proceed for 60 minutes. The development of pink bands, indicating binding of IgA to $E$ coli antigens, was assessed visually.

\section{Culture methods}

Blood and bile were plated undiluted on Mueller-Hinton agar plates, which were incubated at $37^{\circ} \mathrm{C}$ for 24 hours. If no growth was seen at 24 hours, the plates were incubated for an additional 24 hours before being recorded as showing no growth.

In phase 2 group 1 rats, a $2.0 \mathrm{~g}$ piece of the right hepatic lobe was mechanically ground into a homogenate by trituration with sterile glass beads, and the homogenate was suspended in $2 \mathrm{ml}$ of sterile normal saline. A 50 $\mu l$ unfiltered aliquot of each homogenate was plated and cultured overnight at $37^{\circ} \mathrm{C}$, and bacterial colonies were counted the next morning. The entire liver was removed from rats in phase 2 group 2 . It was weighed and homogenised, and the homogenate was suspended in $20 \mathrm{ml}$ of sterile normal saline. Each sample was filtered through fine mesh sterile gauze. A $100 \mu l$ filtered aliquot of each suspension was serially diluted in sterile PBS to a dilution of 1:30 000; four $20 \mu \mathrm{l}$ drops of each diluted sample were plated to make four rows on a Mueller-Hinton agar plate.
Plates were incubated overnight at $37^{\circ} \mathrm{C}$, and bacterial colonies were counted the next morning.

\section{Results}

Phase 1

Bile collected at 3, 5, 7, 9, and 14 days after injection from immunised and control rats was analysed by ELISA for anti- $E$ coli IgA ('specific IgA'). Specific IgA was present in bile samples collected from immunised rats 7,9 , and 14 days after immunisation (data not shown).

Phase 2, group 1

Bile collected seven days after Peyer's patch injection with killed $E$ coli (immunised rats) or with sterile saline (control rats) was analysed by ELISA. Specific IgA levels, expressed as OD $_{490}$ values, were higher in bile from immunised rats than from controls, confirming immunisation (Fig 1). Western blotting showed that rats injected with killed $E$ coli generated a biliary IgA response to multiple antigens of $E$ coli (Fig 2).

One of the 11 control rats died of sepsis 48 hours after bacterial inoculation of the common bile duct. A bile leak was found in one immunised rat at postmortem examination. One control and one immunised rat died of anaesthetic complications before the bacterial inoculation step. All other immunised
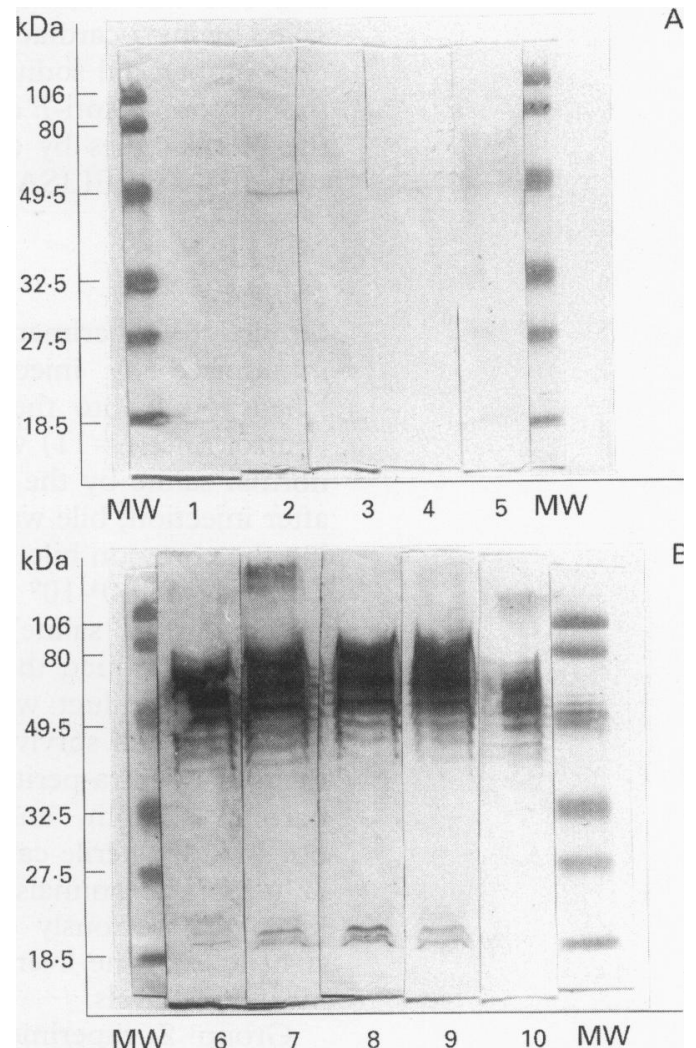

Figure 2: Western blot of $\mathrm{E}$ coli antigens with biliary $\operatorname{IgA}$ from rats in phase 2, group 1. See text for method. $(A)$ Lanes 1-5 show results for individual bile samples from controls rats; (B) lanes 6-10 show results for individual bile samples from immunised rats. IgA from immunised rats binds to numerous antigens of $\mathrm{E}$ coli. Positions of molecular weight (MW) markers are shown ( $k D a)$. 


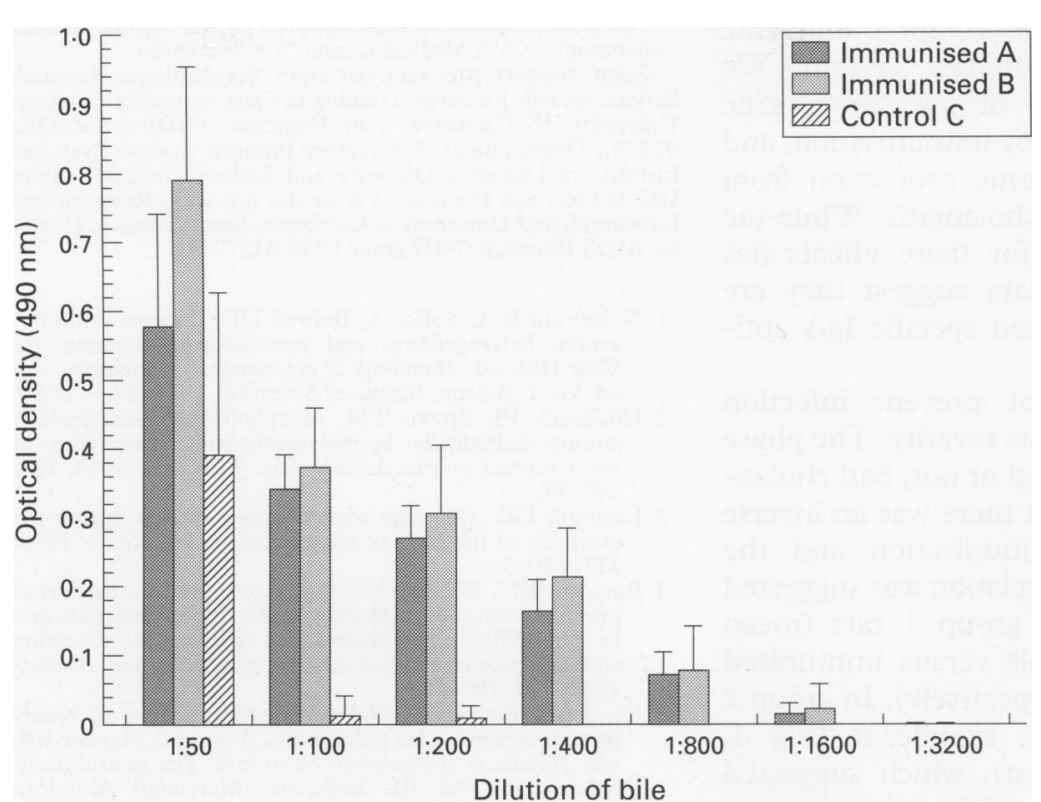

Figure 3: Results of ELISA for anti-E coli IgA in bile from immunised rats (immunised $A$, $n=12$ ); immunised $B, n=12$ ) and from control rats (control $C, n=12$ ) in phase 2, group 2. Anti-E coli IgA levels are expressed as optical density $\left(O D_{490}\right)$. Mean values and standard deviations are shown. See the Table for information about experimental conditions applicable to subgroups $A$ and $B$.

rats $(n=11)$ and control rats $(n=9)$ survived until death 72 hours after bacterial challenge.

Blood, bile, and liver tissue collected at death were cultured. $E$ coli was present in bile cultures from all rats in this group, but blood cultures were negative for bacterial growth. The results of the cultures of $50 \mu l$ of undiluted liver homogenates suggested there was an inverse correlation between immunisation and bacterial colony counts from the liver. For example, the mean bacterial colony count for liver homogenates from nine control rats was 523 per culture plate. The corresponding mean value for liver homogenates from 11 immunised rats was 71 colonies per culture plate. While these results were statistically significant ( $\mathrm{p}=0.043$, Student's $t$ test), only a $2.0 \mathrm{~g}$ piece of the right hepatic lobe from all rats in phase 2, group 1 was processed and cultured. Concern arose over whether this specimen was representative of bacterial distribution throughout the liver. Therefore, to check on the correlation between immunisation and bacterial colony counts, the entire liver was processed and cultured in group 2 rats.

\section{Phase 2, group 2}

The results of ELISA of bile samples from this group of rats were similar to the corresponding results for group 1 rats, in that specific $\operatorname{IgA}$ levels ( $O D_{490}$ values) were higher in bile from immunised rats than from controls (Fig 3). No difference was seen in specific IgA levels between rats orally boosted with $E$ coli plus cholera toxin versus $E$ coli alone (Fig 3 ). The incidence of systemic sepsis after $E$ coli inoculation of the bile duct was $50 \%$ in control rats (six of 12 controls) compared with $4 \%$ (one of 24) in immunised rats $\left(p=0.005 ; \chi^{2}\right.$ test). Of the 12 control rats, four died of sepsis and two others were clinically septic when killed. All 12 rats injected with killed $E$ coli and boosted with killed $E$ coli plus cholera toxin, and 11 of 12 rats injected and boosted with killed $E$ coli alone, survived until killed and were not bacteraemic or clinically septic. One rat that was immunised and boosted with killed $E$ coli alone died of sepsis 48 hours after administration of viable $E$ coli.

Blood, bile, and liver tissue were collected at death and cultured. Cultures of blood from the two control rats that were septic when killed grew $E$ coli. There was no growth of $E$ coli in blood cultures from the six control rats that were not septic when killed or from the 23 immunised rats that survived until killed. All bile cultures from immunised and control rats grew $E$ coli. Serial dilution and culture of liver homogenates showed an inverse correlation ( $p=0.024$; Student's $t$ test) between immunisation and $E$ coli colony counts (Fig 4).

\section{Discussion}

Immunoglobulin $A$ is the predominant immunoglobulin of the mucosal immune system and the major antibody in bile.$^{5-8}$ In rats, about $85 \%$ of biliary IgA is believed to be derived from hepatocyte transport and secretion of circulating polymeric IgA into bile. .-79-11 $^{-1}$ The remainder of biliary IgA is synthesised by antibody secreting cells located beneath the bile duct epithelium. ${ }^{5-7} 12$

Previous work has shown that secretion of antigen specific IgA into bile can be induced by antigen administered by the following routes: oral ${ }^{6}{ }^{13-15}$; injection into the intestinal lumen ${ }^{10} 16$; intra-peritoneal injection ${ }^{817}$; and injection into Peyer's patches. ${ }^{6} 121317-19$ The available evidence suggests that specific IgA contributes to protection of the biliary system and upper gastrointestinal tract by preventing attachment of bacteria, protozoan parasites, and viruses to epithelial cells. ${ }^{620}$ Furthermore, IgA directed against cholera toxin prevents intestinal secretion induced by this toxin. ${ }^{6}$ While IgA is not very effective for opsonisation or for activating the complement cascade, it may be involved in killing bacteria via antibody dependent cytotoxicity reactions. ${ }^{6}$

The objective of this study was to discover if the presence of antigen specific biliary IgA con-

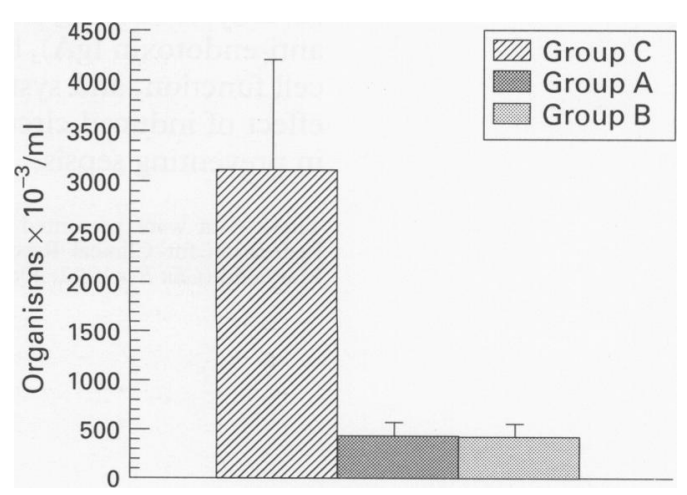

Figure 4: Quantitative culture of $\mathrm{E}$ coli from liver homogenates from rats in phase 2, group 2, expressed as mean numbers of organisms per ml of liver homogenate. $p=0 \cdot 024$, comparing subgroup $C(n=8)$ with subgroups $A$ $(n=11)$ and $B(n=12)$, by Student's t test. 
ferred protection against a direct antigenic challenge in the hepatobiliary system. We found that high values of antigen specific biliary IgA were induced by immunisation, and that they did provide some protection from experimentally induced cholangitis. While the mechanism responsible for these effects has not been proved, the data suggest they are attributable to the induced specific IgA antibody.

Immunisation did not prevent infection altogether but mitigated its severity. The phase 2 rats, whether immunised or not, had cholangitis (culture results), but there was an inverse correlation between immunisation and the extent of infection. A correlation was suggested in the results from the group 1 rats (mean colony counts in controls versus immunised rats were 523 and 71 , respectively). In group 2 rats this correlation was significant (Fig 4, $\mathrm{p}=0.024$, Student's $t$ test), which suggested that the immunisation inhibited intrahepatic proliferation of $E$ coli.

Immunisation with killed $E$ coli also provided (phase 2, group 2) considerable protection against systemic sepsis. In group 1, despite higher levels of specific biliary IgA in immunised rats than in controls, the clinical course after bacterial challenge was similar.

We concluded from the group 1 data that, while an effect of immunisation was present (based on liver homogenate colony counts), the severity of the bacterial challenge was insufficient to change the overall clinical course. In group 2 , the bacterial challenge was increased, and the clinical effects were more striking. As noted above, systemic sepsis was present in six of 12 control rats and in one of 24 immunised rats in group 2. Therefore, the data suggest that, in addition to inhibiting bacterial proliferation within the hepatobiliary system, immunisation inhibited bacterial translocation into the systemic circulation. This may result from antibody antigen complex formation, which is known to prevent epithelial attachment ${ }^{620-22}$ and translocation.

In conclusion, our data show that intestinal immunisation with $E$ coli in rats protected against $E$ coli induced cholangitis and systemic sepsis. Additional studies are needed to further define the function of biliary IgA as well as other hepatobiliary factors that influence the severity of cholangitis, such as endotoxin (and anti-endotoxin IgA), bile composition, Kupffer cell function, and systemic factors, such as the effect of induced circulating immunoglobulins in preventing sepsis.

These data were presented in May 1992, at the American Federation for Clinical Research meeting held in Baltimore, Maryland (Clin Res 1992; 40: 287A).
The research protocol was approved by the Animal Studies Subcommittee, VA Medical Center, San Francisco.

Grant support was received from the National Research Service Award: Research Training in Gastrointestinal Surgery, University of California, San Francisco NIH grant DK07573); Development of Secretory Immune System, National Institute of Diabetes, Digestive and Kidney Diseases (Gran DK-38436), San Francisco VA Center for AIDS Research and Education, and University of California, San Francisco, Center for AIDS Research (NIH grant 1P30 AI27763).

1 Nakamura RM, Voller A, Bidwell DE. Enzyme immunoassays: heterogeneous and homogeneous systems. In Weir DM, ed. Handbook of experimental immunology. 4th ed. Vol 1. Boston: Blackwell Scientific, 1986: 27.1-27.20.

2 Hitchcock PJ, Brown TM. Morphological heterogeneity among Salmonella lipopolysaccharide chemotypes in silver-stained polyacrylamide gels. $\mathcal{f}$ Bacteriol $1983 ; 154$ 269-77.

3 Laemmli UK. Cleavage of structural proteins during the assembly of the head of bacteriophage T4. Nature 1970; 227: $680-5$.

4 Burnette WN. 'Western blotting': electrophoretic transfer of proteins from sodium dodecyl sulfate-polyacrylamide gels to unmodified nitrocellulose and radiographic detection with antibody and radioiodinated protein A. Anal Biochem 1981; 112: 195-203.

5 Jones AL, Burwen SJ. Pathways and functions of biliary protein secretion. In: Schultz SG, Forte JG, Rauner BB eds. Handbook of physiology. Section 6: The gastrointestinal system. Vol III. Bethesda, Maryland: American Physiological Society, 1989: 663-75.

6 Brown WR, Kloppel TM. The liver and IgA: immunological, cell biological and clinical implications. Hepatology 1989; 9: 763-84.

7 Manning RJ, Walker PG, Carter L, Barrington PJ, Jackson GDF. Studies on the origins of biliary immunoglobulins in rats. Gastroenterology 1984; 87: 173-9.

$8 \mathrm{Wu}$ H-Y, Russell MW. Antibody-secreting cell responses in the mouse liver. Immunology 1992; 77: 443-8.

9 Jones AL, Hradek GT, Schmucker DL, Underdown BJ. The fate of polymeric and secretory immunoglobulin A after retrograde infusion into the common bile duct in rats. Hepatology 1984; 4: 1173-83.

10 Altorfer J, Hardesty SJ, Scott JH, Jones AL. Specific antibody synthesis and biliary secretion by the rat liver after intestinal immunization with cholera toxin. Gastroenterology 1987; 93: 539-49.

11 Reuben A. Biliary proteins. Hepatology 1984; 4: 46-50S.

12 Jackson GDF, Hansen PGC, Underdown BJ. Further evidence that hepatic sources confer biliary antibody in the rat. Immunology 1992; 76: 397-401.

13 Dahlgren UIH, Wold AE, Hanson LÅ, Midtvedt T. Expression of a dietary protein in $\mathrm{E}$. coli renders it strongly antigenic to gut lymphoid tissue. Immunology 1991; 73: 394-7.

14 Dahlgren UI, Wold AE, Hanson LA, Midtvedt T. The secretory antibody response in milk and bile against fimbriae and LPS in rats monocolonized or immunized in the Peyer's patches with Escherichia coli. Immunology 1990; 71: 295-300.

15 Elson CO, Ealding W. Generalized systemic and mucosal immunity in mice after mucosal stimulation with cholera immunity in mice after mucosal stimu

16 McKenzie SJ, Halsey JF. Cholera toxin B subunit as a carrier protein to stimulate a mucosal immune response. f Immunol 1984; 133: 1818-24.

17 Dunkley ML, Husband AJ. The induction and migration of antigen-specific helper cells for IgA responses in the intestine. Immunology 1986; 57: 379-85.

18 Dunkley ML, Husband AJ. Distribution and functional characteristics of antigen-specific helper $T$ cells arising characteristics of antigen-specific helper Toells arising 475-82.

19 Nilsson K, Dahlgren UIH, Hanson LA. Different origins of IgA antibodies with various antigen specificities appearing in rat bile. Scand f Immunol 1988; 28: 547-51.

20 Wold AE, Mestecky J, Tomana M, Kobata A, Ohbayashi H, Endo $\mathrm{T}$, et al. Secretory immunoglobulin A carries oligosaccharide receptors for Escherichia coli type $1 \mathrm{fim}$ brial lectin. Infect Immun 1990; 58: 3073-7.

21 Dahlgren UIH, Svanvik J, Edén CS. Antibodies to Escherichia coli and anti-adhesive activity in paired serum, hepatic and gall bladder bile samples. Scand $\mathscr{f}$ Immunol 1986; 24: 251-60.

22 McQueen CE, Boedeker EC Le M, Hamada Y, Brown WR. Mucosal immune response to RDEC-1 infection: study of lamina propria antibody-producing cells and biliary antibody. Infect Immun 1992; 60: 206-12. 